\title{
Trisomy 18
}

National Cancer Institute

\section{Source}

National Cancer Institute. Trisomy 18. NCI Thesaurus. Code C36626.

A chromosomal abnormality consisting of the presence of a third copy of chromosome 18 in somatic cells. 